\title{
Toxicity of waste from a parathion industry at the Danish North Sea coast
}

\author{
JAN Bö̈TIUS \\ The Danish Institute of Fisheries and Marine Research, Charlottenlund, \\ Denmark
}

KURZFASSUNG: Giftigkeit von Abwässern einer Parathion-Industrie an der dänischen Nordseeküste. Eine chemische Fabrik am Limfjord erhöhte ab 1961 ihre Produktion des Insektenvertilgungsmittels Parathion, eines flüssigen Thiophosphats, und führte ihre Abwässer, damals 700 bis $800 \mathrm{~m}^{3}$ täglich, durch eine Pipeline in die Nordsee. 1964 wurden viele Heringe und Hummer an dieser Küste tot gefunden, die letztgenannten in einer Entfernung bis zu $60 \mathrm{~km}$. Erste Versuche ergaben, daß die Abwässer noch bei 25000 facher Verdünnung auf den Guppy (Lebistes reticulatus) und nod bei 50000 facher Verdünnung auf Hummer (Homarus gammarus) tödlich wirken. Nach dänischem Gesetz wurde der Fall vom Gericht entschieden. Die Experimente der Gerichtssachverständigen ergaben, daß die Abwässer der Äthylparathionproduktion etwa $200 \mathrm{mal}$ giftiger sind als die einer gesättigten Parathionlösung. Das örtliche Gericht setzte 1965 die obere Giftgrenze bei 1:50 für diese Abwässer fest: in 50fach verdünntem Abwasser mußten Guppys 24 Stunden lang überleben können.

\section{INTRODUCTION}

The industry dealt with in this paper is located in northern Jutland on a tongue of land which separates the Limfjord from the North Sea. About $6 \mathrm{~km}$ to the north the Limfjord communicates with the North Sea. The factory was erected in 1953; it produced weedkillers ("plant hormones") as well as insecticides.

According to Danish legislation concerning water pollution the conditions for outlet of waste water were determined by a local court. The waste must be discharged by a pipeline into the North Sea; the intake of cooling water was allowed from the Limfjord. The waste water was not permitted to contain chlorocresols or other substances causing bad after-taste of fish and other commercially used marine organisms.

In 1961 the weedkiller production was discontinued and the production of the insecticide parathion increased.

During the summer of 1964 reports on fish and lobster kills were received from the North Sea coast and also from the Limfjord. Few of them were verified in a satisfactory manner, but as far as the North Sea coast was concerned, the following facts remained: (1) fish (young herring, Clupea barengus) were killed in 
numbers near the outlet of the plant; (2) lobsters (Homarus gammarus) died in numbers along a ca. $60 \mathrm{~km}$ coastline north of the plant. Dying lobsters with badly co-ordinated leg movements were occasionally observed along the shoreline mentioned.

Random samples of waste water from the industry were toxicologically tested by the Danish Fisheries Research. This preliminary test revealed that the waste water was still lethal to fish (Lebistes reticulatus) after 25,000 times dilution, and to lobsters after 50,000 times dilution. It was further shown that Lebistes killed in 500 times diluted waste water caused death to lobsters if eaten by them.

With this background the Ministry of Fisheries requested the industry to bring the case before the court. A committee of five experts, covering the fields of chemistry, toxicology and fisheries biology was made up. The results obtained by this committee, especially in regard to the toxicological investigations, are dealt with below.

\section{TOXICOLOGICAL EXPERIMENTS}

The waste water samples

Parathion production involves two steps: (A) processing of methyl or ethyl thiophosphoryl chloride, and (B) reaction between methyl (or ethyl) thiophosphoryl chloride and paranitrophenol, resulting in methyl (or ethyl) parathion.

Processes (A) and (B) were run simultaneously, each of them either as methyl or ethyl production. This means four combinations were possible, each of them leading to a special type of waste water. Only the following two types were investigated: "methyl parathion production" which stands for simultaneous A (methyl) and B (methyl) production, and "ethyl parathion production" which means simultaneous A (ethyl) and B (ethyl) production. The waste water samples used in the toxicological experiments were mixtures of equal parts of separate samples taken from the effluent at intervals of 3 hours during a 24 hour period.

Before preparation of experimental solutions the stock solutions were well shaken. For filtering ordinary filter paper was used. Benzine extractions were made by shaking a ca. $100 \mathrm{ml}$ sample for 5 minutes with an equal volume of benzine.

\section{The toxicological test}

Female Lebistes reticulatus weighing about $100 \mathrm{mg}$ were used as test fish, usually 5 to 15 individuals per test. The test solutions were prepared via dilution with aerated tap water to the proper concentrations. Experiments were carried out in $200 \mathrm{ml}$ covered glass beakers at about $20^{\circ} \mathrm{C}$; the test fish had been acclimatized to this temperature weeks before the experiment.

The survival time was defined in terms of the number of minutes elapsing from the moment of transfer into the toxic solution until $50 \%$ of the fish were laying at the bottom in a permanently paralyzed condition. 
Toxicity of waste during methyl parathion production

Figure 1 shows the degree of toxicity of waste water during a "methyl period". The sample becomes almost non-toxic when diluted 200 times. Removal of suspen-

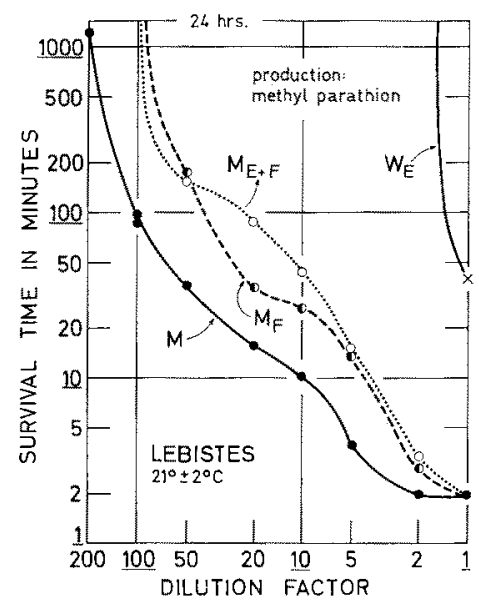

Fig. 1: "Dilution-action" graphs of waste water during methyl parathion production. M: untreated waste water; $\mathrm{M}_{\mathrm{F}}$ : filtered $\mathrm{M} ; \mathrm{M}_{\mathrm{E}+\mathrm{F}}$ : benzine extracted, filtered $\mathrm{M}$; $\mathrm{W}_{\mathrm{E}}$ : benzine extracted tap water (control)

ded matter by paper filtering reduces the toxicity only by a very limited amount; the effect of benzine extraction after filtering is very much the same.

\section{Toxicity of waste during ethyl parathion production}

The degree of toxicity of waste water of an "ethyl period" is definitely different from that of a "methyl period". Figure 2 indicates that the untreated ethyl sample has to be diluted about 10,000 times before its toxicity is eliminated. The effect of filtering is evident: toxicity is lowered by a factor of 200 . Benzine extraction also causes low toxicity, and combined extraction and filtering reduces the toxicity even further.

It is concluded that, during ethyl parathion production, the suspended matter of the waste water contains a certain factor (" $x$ ") which increases the toxicity of the waste 200 fold above that of the dissolved matter.

The waste water sample (Fig. 2) was analyzed; it contained $1600 \mathrm{ppm}$ paranitrophenol and $14 \mathrm{ppm}$ ethyl parathion (not far from saturation). Stock solutions of the two substances were made in the concentrations analytically stated, and tested toxicologically applying different dilutions. In Figure 3 the results of these tests are compared with the toxicity of untreated, as well as filtered, waste water samples. 
It is seen from Figure 3 that the stock solutions of ethyl parathion and paranitrophenol have a lower level of toxicity corresponding to a dilution factor of about 50 . This is also true for the filtered waste water. The "dilution - action" graph

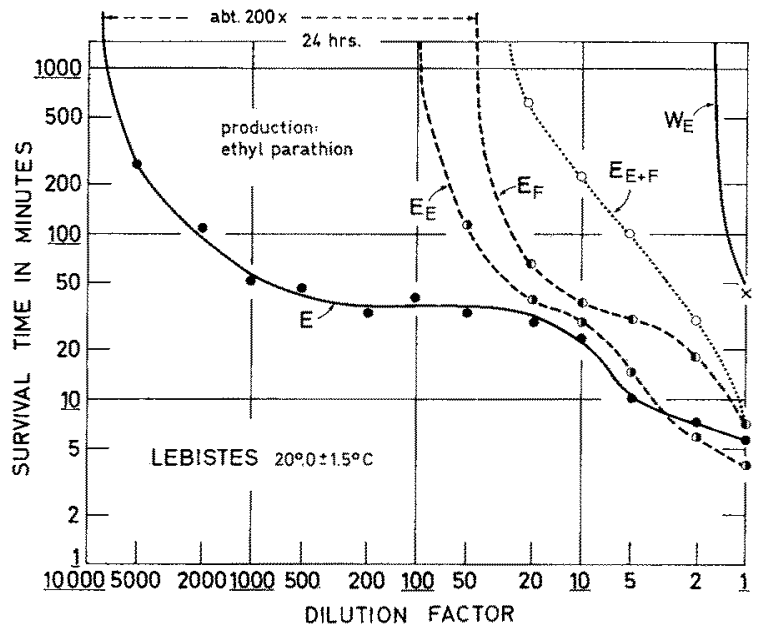

Fig. 2: "Dilution-action" graphs of waste water during ethyl parathion production. E: untreated waste water; $\mathrm{E}_{\mathrm{E}}$ : benzine extracted $\mathrm{E}_{\mathrm{F}} \mathrm{E}_{\mathrm{F}}$ : filtered $\mathrm{E}_{;} \mathrm{E}_{\mathrm{E}+\mathrm{F}}$ : benzine extracted, filtered $\mathrm{E} ; \mathrm{W}_{\mathrm{E}}$ : benzine extracted tap water (control)

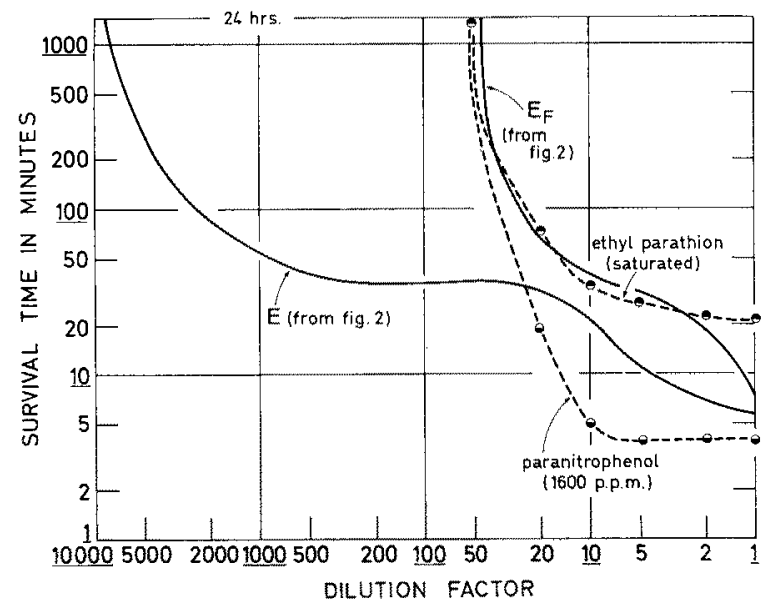

Fig. 3: "Dilution-action" graphs of a saturated ethyl parathion solution and of a $1600 \mathrm{ppm}$ paranitrophenol solution compared with the corresponding graphs of untreated and filtered waste water during ethyl parathion production (from Fig. 2)

of the ethyl parathion solution and that of the filtered waste water are very much alike. The paranitrophenol solution, however, causes significantly shorter survival times. This phenomenon might have chemical as well as physiological causes.

From the results illustrated in Figure 3 it is concluded that the analytically 
stated concentrations of ethyl parathion and paranitrophenol in the untreated waste water are sufficient to account for the total toxicity of the filtered waste water but not for the high toxicity (" $x$ ") of the suspended matter.

Ethyl thiophosphoryl chloride is also present in the waste. The saturated solution becomes non-toxic after a 5 time dilution. A possible role of this substance as factor " $x$ " would require amounts which surpass by far those processed by the industry.

Finally, the chemists of the committee made extensive analytical studies of the waste water. The main result was the indication of a special compound, a byproduct of the parathion synthesis, which is considered to be identical with the factor " $x$ ".

\section{THE COURT'S DECISION}

The toxicological experiments described above were made from January to March, 1965; during this period, the total outlet from the industry amounted to 700 to $800 \mathrm{~m}^{3}$ of waste water per day. From this figure the theoretical pollution capacity of the industrial plant during ethyl parathion production was roughly estimated: wastes discharged during one year are sufficient to poison a water mass of about $2 \mathrm{~km}^{3}$ to an extent that the fish would die. In order to assess the actual pollution capacity in situ information was needed concerning the stability of the toxic substances and the hydrographical conditions of the recipient waters.

It was proved experimentally that the toxicity of waste water samples did not change significantly after half a year storage at room temperature. The stability of diluted waste waters was not tested.

The court decided not to prolong the case by arranging for special hydrographical investigations. Calculations by an expert indicate, however, a reasonable chance that lethal dilutions of waste water could still enter the Limfjord occasionally. In June 1965 the court ordered purification of the wastes; it was left to the industry to choose proper methods. The upper limit of toxicity was fixed at 1/50 which means: waste water diluted 50 times must allow test guppies to survive longer than 24 hours. This was the first Danish court decision on pollution problems, expressed in toxicological terms.

The 1/50 limit should be maintained only as long as the industry kept the total outlet below $1000 \mathrm{~m}^{3}$ per day; if this daily amount was exceeded, the limit should be lowered gradually to $1 / 25$ at an outlet rate of $2000 \mathrm{~m}^{3}$ per day. Soon after the court's decision the industry requested permission to increase its parathion production. It was decided in May 1966 that daily rates of waste products increasing from 2000 to $6000 \mathrm{~m}^{3}$ should be followed by a lowering of the toxic limit from $1 / 25$ to $1 / 15$.

Since June 1965, the Ministry of Fisheries organized a continuous control of toxicity and flow rate of the waste water. Up to the present time (September, 1967) this control has demonstrated the ability of the industry to meet the demands requested by the court, and no further reports on fish or lobster kills have been received. 


\section{SUMMARY}

1. The toxicity to fish (Lebistes reticulatus) of the waste waters from a parathion producing industrial plant was investigated experimentally.

2. On the basis of a court's decision, toxicologically defined limits, regarding the toxicity of the waste water released and its total amount per day, have been laid down.

3. These measures proved satisfactory. No further reports of damages to fishes and lobsters near the discharge area have been received.

\section{Discussion following the paper by BoËTrus}

Lillelund: Ich halte Toxizitätsuntersuchungen, welche die Toleranz von Versuchstieren für einen Aufenthalt von einem Tag oder wenigen Tagen im Testmedium prüfen, für höchst bedenklich, vor allem dann, wenn sie die Basis für Unbedenklichkeitserklärungen sind. Alle neueren Untersuchungen deuten darauf hin, daß es unbedingt darauf ankommt, die Wirkung von Abfallstoffen über einen längeren Zeitraum zu studieren, da Schäden, die durchaus zur Bestandsvernichtung führen können, oft erst nach längerer Zeit erkennbar werden. Toxizitätsuntersuchungen sollten daher grundsätzlich schon in der "ersten Phase" so lange ausgedehnt werden, bis sich die täglichen und 3tägigen Sterblichkeitsraten einem Ganzwert nähern.

Bö̈тrus: In my figures shown I have fixed the maximum experimental time to 24 hours because this period is involved in the definition of the level of toxicity set by the court mentioned. None of the lett branches of my graphs are extrapolatory constructed. My results (not mentioned in my text) show that any fish surviving a given toxic solution for 1 day will also survive for 3 days. I do, however, certainly agree with Dr. LnLelund that really longtermed experiments are desirable in order to obtain the best possible judgement. The present experiments, however, had necessarily to be made very fast. At that time the industry was operating with a very low purification effect and the court was in need of experimental evidence in order to expedite the decision.

KINNE: Leider kommt die Notwendigkeit, mögliche biologische Konsequenzen von Abwassereinleitungsmaßnahmen zu beurteilen, häufig aus heiterem Himmel auf uns zu. Es gilt dann, mit Hilfe von Schnelltests wenigstens eine Grobbeurteilung der Giftigkeit zu ermöglichen. Diese Zeitnot verträgt sich nicht mit den Erfordernissen gründlicher und langfristiger wissenschaftlicher Studien. Ich teile daher die von Herrn Lillelund zum Ausdruck gebrachren Bedenken. Auf der anderen Seite wird man sich in bestimmten Fällen der Notwendigkeit rascher Grobtests nicht verschließen können. Mortalitätsuntersuchungen stellen einen wichtigen Schnelltest dar, dessen wir uns auch in Zukunft bedienen müssen. Allerdings muß die Uberlebensspanne der Versuchstiere in einer vertretbaren Relation zu deren Gesamtlebenserwartung stehen, und dem Mortalitätstest sollten später weitere Tests (Wachstums-, Leistungs-, Reproduktionstest) folgen. Die ökologische Konkurrenzfähigkeit würde, etwa in vereinfachten OKosystemen, ein besonders wichtiges Kriterium liefern. Aber hier beginnt schon die Zukunftsmusik. Wir stecken leider noch sehr in den Anfängen.

LüNEBuRG: Eine ganz kurze Frage bitte: Wo in Limfjord liegt diese Industrie, Herr BoËTIus? BoËrrus: It is situated $6 \mathrm{~km}$ south of the point where the Limfjord communicates with the North Sea. 